\title{
The Stable Isotope Characteristics of Precipitation in the Middle East Highlighting the Link between the Köppen Climate Classifications and the $\delta^{18} \mathrm{O}$ and $\delta^{2} \mathrm{H}$ Values of Precipitation
}

\author{
Mojtaba Heydarizad ${ }^{1}$, Luis Gimeno ${ }^{1, *}$, Rogert Sorí ${ }^{1,2} \mathbb{C}$, Foad Minaei ${ }^{3,4} \oplus$ and Javad Eskandari Mayvan ${ }^{5}$ \\ 1 Centro de Investigación Mariña, Environmental Physics Laboratory (EPhysLab), Campus As Lagoas s/n, \\ Universidade de Vigo, 32004 Ourense, Spain; mojtabaheydarizad@yahoo.com (M.H.); \\ rogert.sori@uvigo.es (R.S.) \\ 2 Instituto Dom Luiz (IDL), Faculdade de Ciências, Universidade de Lisboa, 1749-016 Lisboa, Portugal \\ 3 Department of Geography, Ferdowsi University of Mashhad, Mashhad 917794883, Iran; \\ Minaei.Foad@yahoo.com \\ 4 Geographic Information Science/System and Remote Sensing Laboratory (GISSRS. Lab), \\ Ferdowsi University of Mashhad, Mashhad 9177794883, Iran \\ 5 Regional Water Company of Khorasan Razavi, Mashhad 9185916196, Iran; Jeskandari_65@yahoo.com \\ * Correspondence: 1.gimeno@uvigo.es
}

\section{check for}

updates

Citation: Heydarizad, M.; Gimeno, L.; Sorí, R.; Minaei, F.; Mayvan, J.E. The Stable Isotope Characteristics of Precipitation in the Middle East Highlighting the Link between the Köppen Climate Classifications and the $\delta^{18} \mathrm{O}$ and $\delta^{2} \mathrm{H}$ Values of Precipitation. Water 2021, 13, 2397. https://doi.org/10.3390/ w13172397

Academic Editor: Maurizio Barbieri

Received: 11 June 2021

Accepted: 27 August 2021

Published: 31 August 2021

Publisher's Note: MDPI stays neutral with regard to jurisdictional claims in published maps and institutional affiliations.

Copyright: (c) 2021 by the authors. Licensee MDPI, Basel, Switzerland. This article is an open access article distributed under the terms and conditions of the Creative Commons Attribution (CC BY) license (https:/ / creativecommons.org/licenses/by/ $4.0 /)$.

\begin{abstract}
The Middle East is faced with a water shortage crisis due to its semiarid and arid climate In this paper, precipitation as an important part of the water cycle was evaluated in 43 stations across the Middle East using the stable isotope technique to study the parameters which influence the stable isotope content of precipitation. First, the stepwise regression model was applied to determine the main geographical and climatological factors affecting the stable isotopes in precipitation. Secondly, the stepwise model was also used to simulate the stable isotope values in precipitation. Furthermore, due to the notable climatic variations across the Middle East, the precipitation sampling stations were classified into six groups based on the Köppen climate zones. Significant variations in the stable isotope values of precipitation were observed in the stations of each climate zone. Finally, the Middle East meteoric water line was developed for the dry and wet periods based on the average stable isotopes in the studied stations. The developed lines showed a lower slope compared to the GMWL due to the higher air temperature and relative humidity in the Middle East compared to the average global conditions. To conclude, the stable isotope contents in precipitation showed significant temporal and spatial variations due to the notable climatic variations across the Middle East.
\end{abstract}

Keywords: stable isotopes; precipitation; Middle East; Köppen climate classification; stepwise regression

\section{Introduction}

The Middle East is located in the southwest of Asia and is well known for its significant energy resources such as oil and gas. Due to the semiarid and arid climates in large parts of the Middle East, this region always faces a water shortage crisis [1]. During the last few decades, due to the intense growth of the population and industries, the importance of water resources has considerably increased in this region [2]. Therefore, water resources in the Middle East should be studied and continuously monitored by accurate and reliable methods such as stable isotope techniques. These techniques can provide a comprehensive view on the crucial aspects of water resources such as origin, mixture, pollution, and evolution [3-11]. Precipitation is an important element of the water cycle and has a direct and quick effect on the quality and quantity of surface water and groundwater resources [12-15]. Studying the stable isotopes in precipitation provides very important information regarding the moisture origin of precipitation, the parameters which influence moisture in air mass trajectories toward precipitation sampling sites, and the parameters which affect the climate of precipitation sampling sites [16,17]. 
Since Harmon Craig (1961) [18] found that ${ }^{18} \mathrm{O} /{ }^{16} \mathrm{O}$ and ${ }^{2} \mathrm{H} / \mathrm{H}$ ratios in freshwater molecules are correlated with each other, numerous researchers across the world have used the stable isotope technique as a reliable and accurate method to study water resources. Furthermore, the meteorological conditions (such as the sea surface temperature (SST) and the relative humidity of the sea) of the water body from which the moisture originates can be studied using the d-excess values (d-excess $=\delta^{2} \mathrm{H}-8 \times \delta^{18} \mathrm{O}[19]$ ) of the precipitation events. In large-scale and closed water cycle systems, the $\mathrm{d}$-excess values in precipitation are under the dominant influence of the meteorological conditions and the SST of the moisture sources [20-23]. For instance, the precipitation originating from water bodies with high SSTs such as the Mediterranean Sea shows high d-excess values [24-28], while the precipitation originating from low SST water bodies normally shows low d-excess values [28].

The application of stable isotopes in water resources across the Middle East has started since the establishment of the Global Network of Isotopes in Precipitation (GNIP) stations in this region. Numerous GNIP stations exist in most of the countries across the Middle East except for Qatar, Kuwait, and Iraq. Some of these stations (such as Tehran, Kabul, Bahrain, Cairo, Adana, Ankara, Antalya, etc.) have long time series of stable isotope datasets. The stable isotope technique in precipitation has also been applied in numerous studies [16,28-35] across the Middle East, mainly during the last two decades.

Although many studies have been conducted on the water resources across the Middle East using the stable isotope technique, most of them are local studies which cover only small parts of the Middle East. Furthermore, in most of the mentioned studies, the effects of climatic and geographical parameters on the stable isotope content of precipitation have not been properly investigated. In some parts of a recent paper published in the Journal of Hydrology [36], the authors tried to investigate the effect of local and regional parameters on the stable isotope values in precipitation across the Middle East. Although their study was a pioneer work and overcame many shortcomings of previous studies, they should have considered two things. First, they did not consider the seasonal effect on the stable isotope values in precipitation thoroughly. They should have divided the hydrological year to the wet and dry periods and then they should have studied and compared the stable isotope values in precipitation in these two periods. Second, they used the analytic hierarchy process (AHP) technique to evaluate the effect of various regional parameters (teleconnection indices) on the stable isotope values in precipitation. As the AHP technique uses human judgment in its evaluations, its results cannot be completely accurate and reliable and have some uncertainties. In the current study, the authors tried to overcome the shortcomings of the abovementioned study and to present a new way to link the climatological conditions of the study area to the stable isotopes in precipitation.

This study aimed to gather available stable isotope data from the GNIP stations and previous studies to conduct a comprehensive investigation regarding the effects of various climatic and geographical parameters on the stable isotope values of precipitation in the Middle East using stepwise regression model. A map of the spatial distribution of the simulated $\delta^{18} \mathrm{O}, \delta^{2} \mathrm{H}$, and d-excess values in the precipitation of the Middle East obtained by stepwise model is also presented. Furthermore, the link between the stable isotope characteristics of precipitation and the Köppen climate zones in which the studied stations were located was studied. Finally, the meteoric water line of the Middle East was developed based on the stable isotope data in the studied stations. The presented precipitation dataset in the current research will be useful for researchers who study the stable isotopes in precipitation, the climatology, and the isotope hydrogeology across the Middle East.

\section{The Geography and Climatology of the Middle East}

The Middle East is a large area surrounded by Afghanistan and Pakistan in the east, the Red and Arabian Seas in the south, the Caspian Sea in the north, and the Black and Mediterranean Seas in the west. Precipitation and temperature show significant variations across the Middle East [37]. In the arid zones of Iraq, Iran, and the Kingdom of 
Saudi Arabia (KSA), temperatures rise to more than $50^{\circ} \mathrm{C}$, while the Zagros Mountains in western Iran and eastern Iraq experience the very low temperature of $-30^{\circ} \mathrm{C}$ in winter [37]. Precipitation also shows large variations in the Middle East. For instance, the coastal areas of the Caspian Sea receive more than $1800 \mathrm{~mm}$ of annual precipitation [38], while the arid areas in Iran, KSA, and Iraq often receive no or little precipitation for a long time [37]. In addition to spatial variations, precipitation also shows large temporal variations as most parts of the Middle East receive large amounts of annual precipitation during the cold and wet (November to April) period compared to the hot and dry (May to October) period. The moisture causing precipitation events in the Middle East is mainly provided by the Mediterranean (MedT), the continental polar (cP) (also known as the Siberian), the continental tropical (cT) (also known as the Sudan), and the Maritime polar (mP) air masses during the cold and wet period. However, during the hot and dry period, only the maritime tropical (mT) air mass which affects the southeastern part of the Middle East including Pakistan, southeastern Iran, and northern Oman [26] is active (Figure 1).

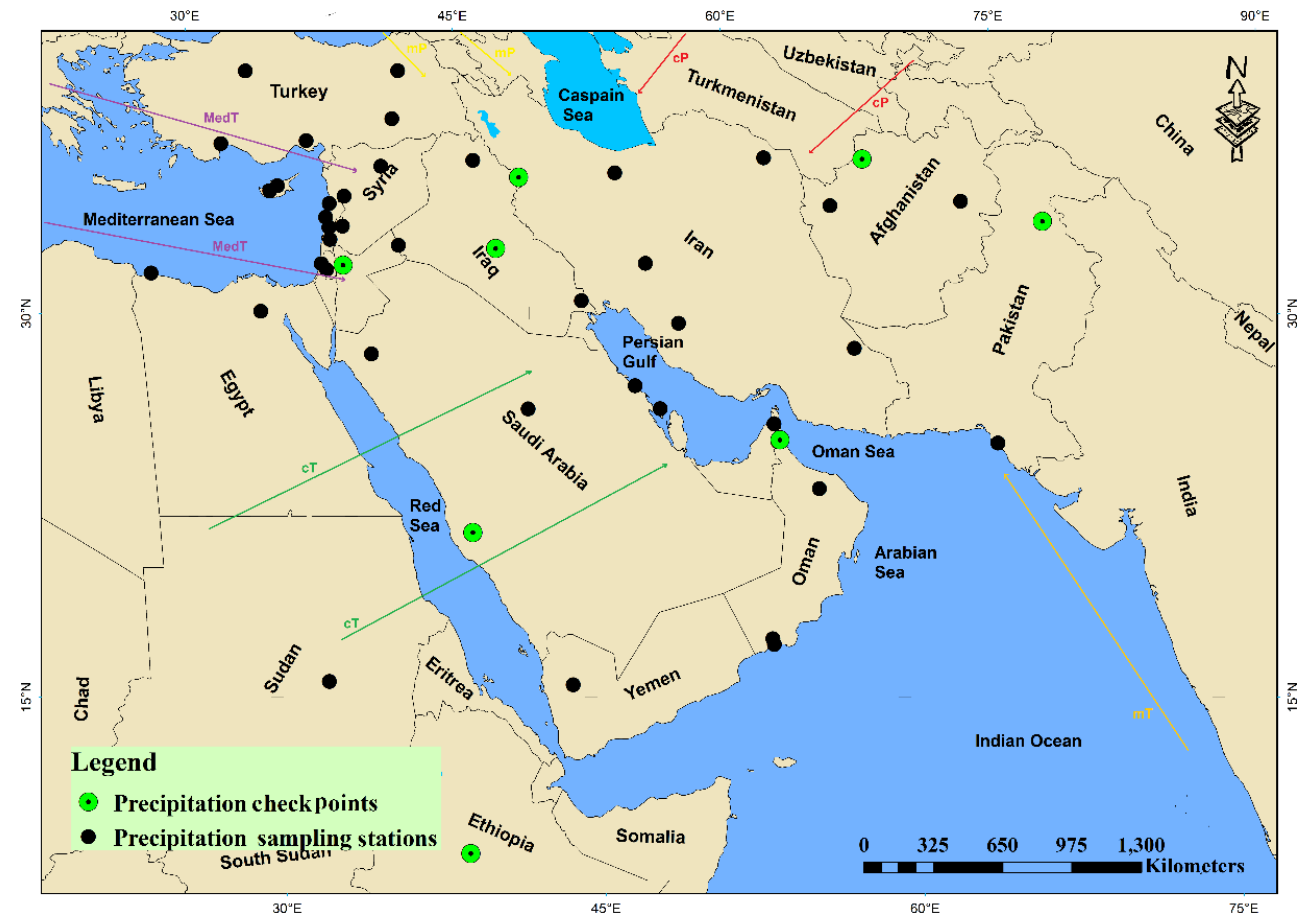

Figure 1. The map of the Middle East including the precipitation sampling stations, the precipitation checkpoint stations, and the main air masses affecting it.

Furthermore, the vertical integrals of northward and eastward water vapor fluxes were used to obtain the vertically integrated moisture flux (VIMF). The VIMF depicts the horizontal rate of water vapor flow per meter across the flow for a column of air extending from the surface of the earth to the top of the atmosphere. The monthly patterns of the VIMF and its divergence for the cold and wet as well as the hot and dry periods are shown in Figure 2. During the months of the cold and wet period, the moisture flux over the Middle East prevails from the west, transporting moisture from the Black Sea, the Mediterranean Sea, the Arabian Sea, and the Persian Gulf. This is in agreement with previous studies $[26,39]$. A visual analysis reveals that the convergence of the moisture flux prevails over the Middle East during the cold and wet period. The upward motions favor convection, which leads to precipitation over the region. On the contrary, the VIMF divergence is mostly observed over $40^{\circ} \mathrm{N}$ from May to August, while convergence is dominant over the Indian Peninsula and the surrounding regions throughout the period, which is in agreement with the Asian summer monsoon. In this period, the VIMF reaches the Middle East from the west (Europe and the Mediterranean Sea) and from the south (the Arabian Sea). 

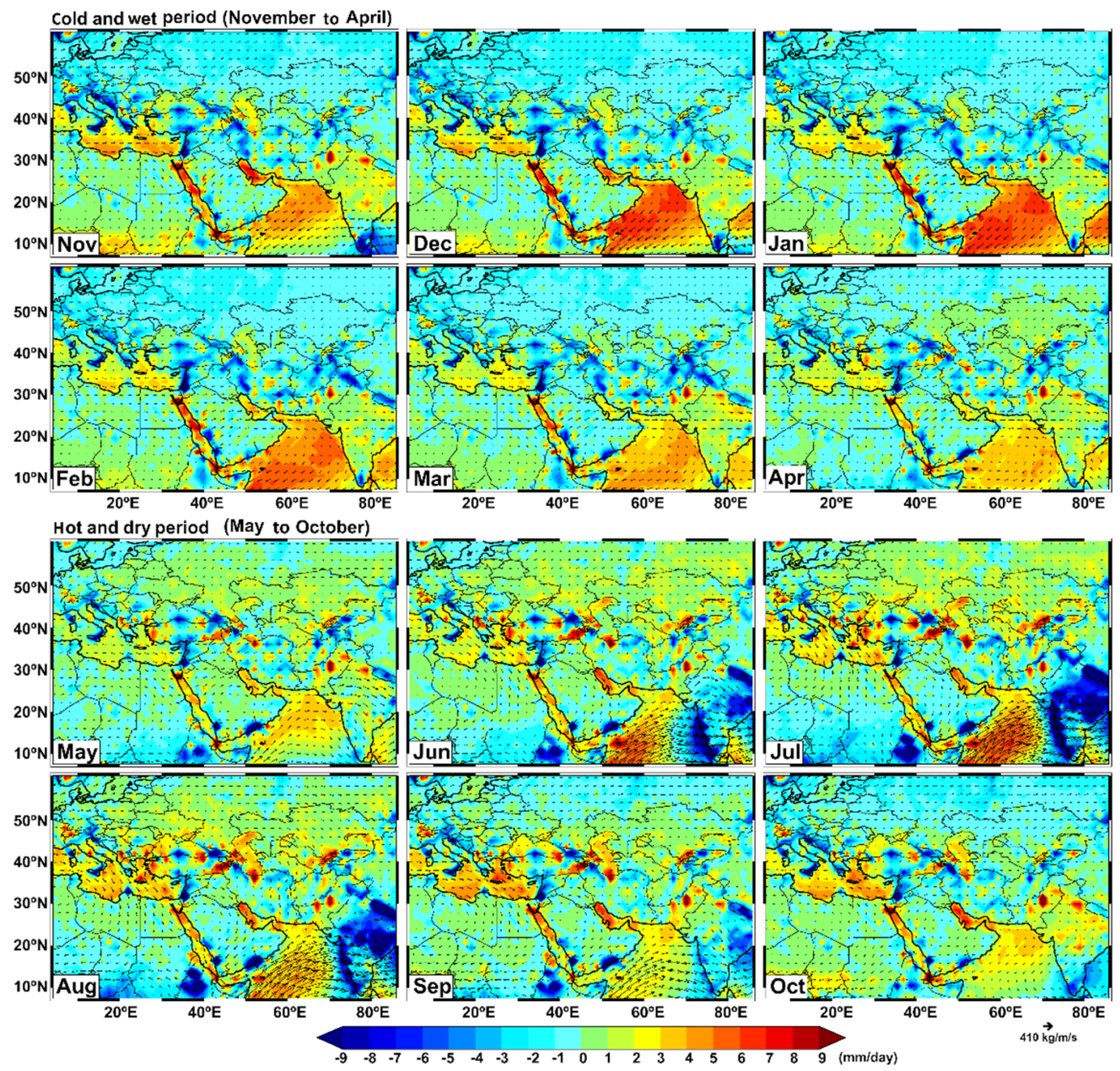

Figure 2. The northward and eastward vertically integrated moisture flux (VIMF) data obtained from the ERA-Interim Reanalysis with a resolution of $1^{\circ} \times 1^{\circ}$ for the period of 1981 to 2015 [40].

Due to the large variations observed in temperature, precipitation amount, elevation, and latitude across the Middle East, various climatic zones exist in it. According to the Köppen classification [41,42], various climatic zones including BWh (arid, desert, and hot), BWk (arid, desert, and cold), BSh (arid, steppe, hot), BSk (arid, steppe, cold), Csa (temperate, dry summer, hot summer), Csb (temperate, dry summer, warm summer), Cfa (temperate, no dry season, hot summer), Dsa (continental, dry summer, hot summer), Dsb (continental, dry summer, warm summer), Dsc (continental, dry summer, cold summer), Dfb (continental, no dry season, warm summer), and Dfc (continental, no dry season, cold summer) exist across the Middle East [43]. However, only the BWh, BSk, and Csa climatic zones cover large parts of the Middle East and the other climatic zones, including BWk, BSh, Csb, Cfa, Dsa, Dsb, Dsc, Dfb, and Dfc, cover small parts of it.

\section{Materials and Methods}

The stable isotope $\left({ }^{18} \mathrm{O}\right.$ and ${ }^{2} \mathrm{H}$ ) data were studied in 43 stations (mostly from the GNIP stations) across the Middle East, while in some stations, including Basreh, Terbil, Erbil [33], Shiraz [44], Isfahan [32], Mashhad [28], and Herat [45], the stable isotope data were extracted from the scientific papers. Precipitation was sampled on a monthly basis using the GNIP cumulative sampling approach. A monthly cumulative precipitation sample represents all the precipitation events that occur in the studied month. To collect monthly samples, the rain samplers were equipped with accumulation containers in the precipitation sampling sites. After each precipitation event, the rain in the gauges was immediately emptied into monthly bottles (high-density polyethylene $1 \mathrm{~L}$ bottles) which could significantly reduce evaporation. The samples collected with this procedure 
represented the weighted monthly average of the stable isotopes of precipitation. At the end of the study month, in each station, $30 \mathrm{~mL}$ bottles were filled with monthly precipitation collected in the monthly bottles.

Several laboratories across the world, such as the IAEA's Isotope Hydrology Laboratory (Vienna, Austria), Central Laboratory of Environmental Isotope Hydrology in Egypt, the Laboratory of AGH University of Science and Technology (Krakow, Poland), Technische Hochschule Laboratory (Darmstadt, Germany), and the Isotope Laboratory of Copenhagen University (Denmark), have analyzed the stable isotopes in the Middle East precipitation using a Delta-Plus XP isotope ratio mass spectrometer (IRMS) (Thermo Finnigan, Germany) or a Los Gatos Research (LGR) Liquid Water Isotope Analyzer Instrument.

The stable isotope values in precipitation are presented in delta notation $(\delta)$ which is the relative deviation of the sample from the Vienna Standard Mean Ocean Water (VSMOW) and is calculated by Equation (1):

$$
\delta^{18} \mathrm{O} \text { sample }=\left(\frac{\left(\frac{{ }^{18} \mathrm{O}}{{ }^{16} \mathrm{O}}\right) \text { sample }}{\left(\frac{{ }^{18} \mathrm{O}}{{ }^{16} \mathrm{O}}\right) \text { reference }}-1\right) \times 1000 \% \text { vs. VSMOW }
$$

The analytical standard uncertainties for most of the samples were $\pm 1 \%$ for $\delta^{2} \mathrm{H}$ and $\pm 0.1 \%$ for $\delta^{18} \mathrm{O}$.

Furthermore, the stepwise regression model was used to determine the effects of various geographical and meteorological parameters on the stable isotope values of precipitation.

The stepwise regression model is a statistical technique which attempts to fit a linear equation between dependent and predictive variables [46] using Equation (2):

$$
Y=\beta 0+\beta 1 \times 1+\beta 2 \times 2+\ldots+\beta n X n+\varepsilon
$$

in which $\beta 0, \beta 1, \beta 2, \ldots$, and $\beta$ n are the parameter values and $\varepsilon$ is the error term. The error term demonstrates the variations of parameter $Y$, which cannot be explained using the linear model.

The independent variables (such as the precipitation amount, latitude, temperature, and elevation) were entered into the stepwise regression model one by one to clarify their significance in it. Then, based on the calculated F-statistics and $p$-values in each independent variable, the parameters which needed to be removed from the model were chosen [47].

The variables with the p-values of more than 0.05 were removed from the model, while the other parameters were considered as the main independent factors in the stepwise regression model. The statistical (regression) analysis used in the stepwise model was performed using the $\mathrm{R}$ programming language [48].

Finally, the stepwise regression model was used to simulate the $\delta^{18} \mathrm{O}, \delta^{2} \mathrm{H}$, and $\mathrm{d}$-excess values in the Middle East precipitation. The spatial distribution maps of these isotopes across this region were developed using QGIS Desktop software [49]. To validate and check the accuracy of the maps developed by the stepwise model, the root mean square error (RMSE) was used [50]. The RMSE (also known as the prediction error) was calculated using Equation (3):

$$
\text { RMSE }=\sqrt{\frac{\sum_{\mathrm{i}=1}^{\mathrm{N}}(\text { predicted } \mathrm{i}-\text { actual } \mathrm{i})^{\wedge} 2}{\mathrm{~N}}}
$$




\section{Results and Discussion}

The arithmetic and weighted means of the $\delta^{18} \mathrm{O}, \delta^{2} \mathrm{H}$, and d-excess values in 43 precipitation sampling sites across the Middle East are tabulated in Supplementary Table S1. Stable isotopes in precipitation can determine very important facts regarding the climatological characteristics of the precipitation sampling sites as well as the characteristics of the moisture sources.

\subsection{The Parameters Affecting the Stable Isotope Values and the Simulation of the Stable Isotopes}

The stable isotope values in precipitation mainly depend on the climatological and geographical conditions of the precipitation sampling site. The effects of the main meteorological (such as air temperature and precipitation amount) and geographical parameters (such as latitude and elevation) on the stable isotope values of precipitation were studied using stepwise regression model. The geographical (latitude and elevation) and meteorological parameters (temperature and precipitation amount) were entered into the stepwise regression model one by one as independent variables, and the insignificant parameters were omitted, as shown in Supplementary Table S2. The results obtained from the stepwise regression model demonstrated that, among the geographical and meteorological parameters, latitude and temperature mainly control the $\delta^{18} \mathrm{O}$ values in the Middle East precipitation, while only latitude has a dominant influence on the $\delta^{2} \mathrm{H}$ values in the precipitation of this region (Sig < 0.05). However, more parameters including precipitation amount, temperature, and elevation affect the d-excess values in the Middle East precipitation.

Furthermore, the $\delta^{18} \mathrm{O}, \delta^{2} \mathrm{H}$, and d-excess values were simulated using stepwise regression. The spatial distribution maps of the stable isotopes in precipitation across the Middle East were prepared based on these simulated parameters using QGIS Desktop software (Figure 3).

To validate the distribution maps of the simulated $\delta^{18} \mathrm{O}, \delta^{2} \mathrm{H}$, and $d$-excess values in precipitation across the Middle East using the stepwise technique, several checkpoints across this region including Amman [51], Karbala [33], Marivan [52], Islamabad [53], and Faryab [54] (besides Taif-al-Hada, Haray, and Addis Ababa from the GNIP stations) were used, as shown in Figure 1. The error maps (the differences between the real and simulated isotopic values) for the Middle East are depicted in Figure 4. In the developed error maps, the northeastern part of the Middle East demonstrates a notable mismatch (as high as $-15.5 \%$ for $\delta^{18} \mathrm{O}$ and $-162 \%$ for $\delta^{2} \mathrm{H}$ ) between the simulated and real data, while most parts of the Middle East show a good match.

In the d-excess error map, a significant mismatch is observed over the northern and southern parts of the Middle East. However, in most western and central parts of the Middle East, a good match is observed between the simulated and real data. In addition to preparing the error maps, the RMSE was also calculated for the stable isotope maps developed by real (using the inverse distance weighting (IDW) technique) and simulated data (using the stepwise model), as shown in Table 1. Lower RMSE values were observed for the maps developed by real data. This confirms their higher accuracy compared to the maps developed by the simulated data. 

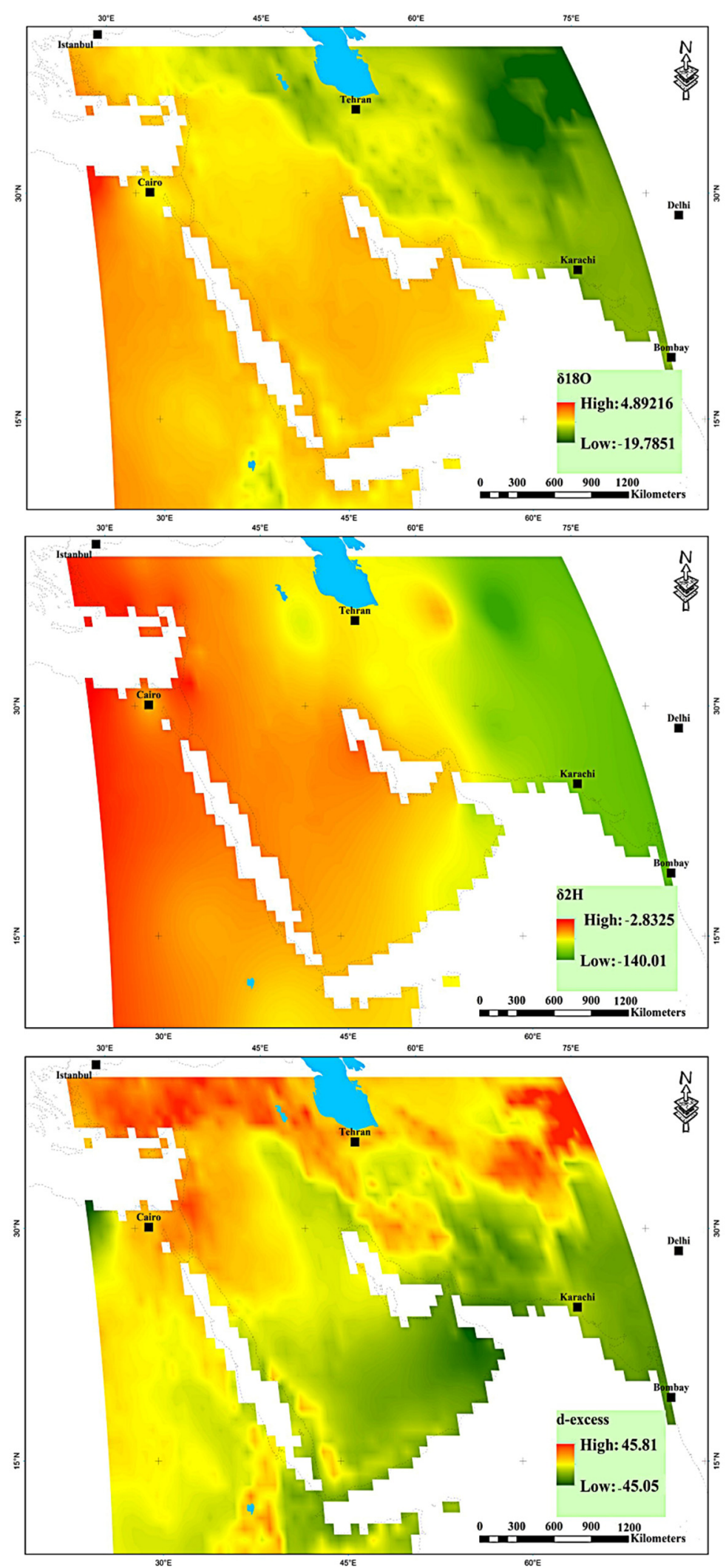

Figure 3. The spatial distribution of the simulated $\delta^{18} \mathrm{O}, \delta^{2} \mathrm{H}$, and d-excess values in precipitation across the Middle East using stepwise regression model. 

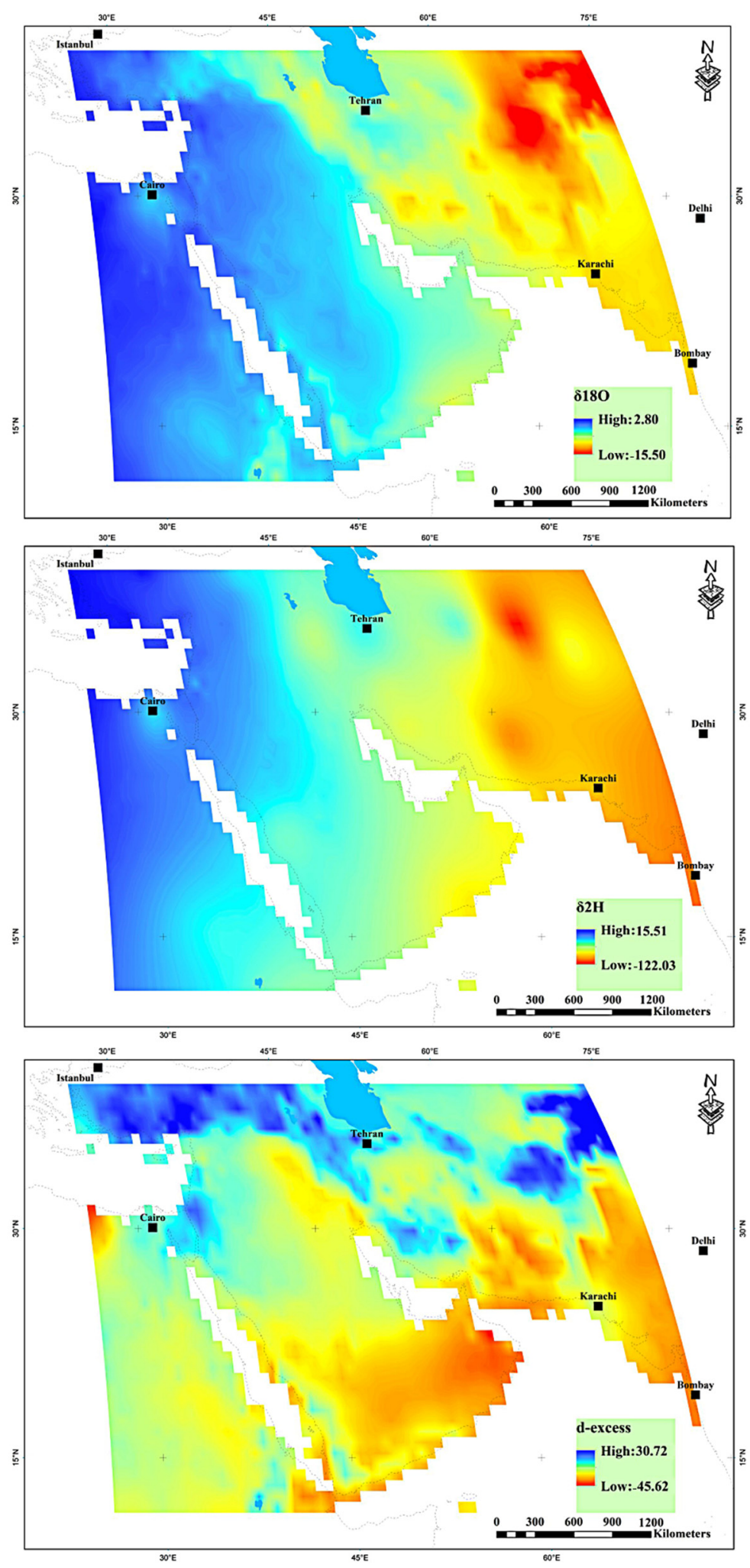

Figure 4. The error maps of the $\delta^{18} \mathrm{O}, \delta^{2} \mathrm{H}$, and d-excess values (the differences between the real and simulated isotopic values) in precipitation across the Middle East. 
Table 1. The RMSE in the stable isotope distribution maps in precipitation across the Middle East.

\begin{tabular}{cccc}
\hline Map Type & $\boldsymbol{\delta}^{\mathbf{1 8}} \mathbf{O}(\mathbf{\%})$ & $\boldsymbol{\delta}^{\mathbf{2}} \mathbf{H} \mathbf{( \% )}$ & d-Excess (\%o) \\
\hline IDW & 1.11 & 13.10 & 7.50 \\
Stepwise model & 7.15 & 30.18 & 12.36 \\
\hline
\end{tabular}

In addition to studying the spatial variations of stable isotopes in precipitation across the Middle East, the temporal variations of stable isotopes in some of the stations in this region were also studied. Among the 43 sampling stations, 12 stations which had enough isotope datasets to conduct temporal studies on the stable isotope values of precipitation were selected. The monthly $\delta^{18} \mathrm{O}$ values at these stations were linked to the monthly temperature variations (due to the temperature-dependent distillation process in the atmosphere [55]) and to the average amount of monthly precipitation. In the continental stations (Nicosia, Cairo, Tehran, Kabul, Ankara, Aaramta, and Adana) across the Middle East, the monthly $\delta^{18} \mathrm{O}$ values demonstrated more depleted values during the cold and wet period than in the hot and dry period. At these stations, monthly precipitation was higher and the average monthly temperature was lower during the cold and wet period compared with the hot and dry period (Figure 5). The inverse correlation between the $\delta^{18} \mathrm{O}$ values in precipitation and the precipitation amount in most of the studied stations in the Middle East is due to the precipitation amount effect. Among the studied continental stations, only in Khartoum, most of the annual precipitation occurred during the hot period. The precipitation moisture over the Sahelian-Sudan region originates from the local evaporation as well as such regions as the Western Sahel, the Guinea Coast, Central Africa, and the Mediterranean Sea [56]. During the hot and dry period, the Guinea Coast and the Mediterranean Sea are the most important moisture sources for the rainiest months (July and August), while Central Africa has its maximum contribution during September. The wind direction also changes from the north in July to the southwest in August and to the northeast in September. This explains the seasonality of the moisture contribution and precipitation, which is related to the migration of the Intertropical Convergence Zone $[56,57]$.

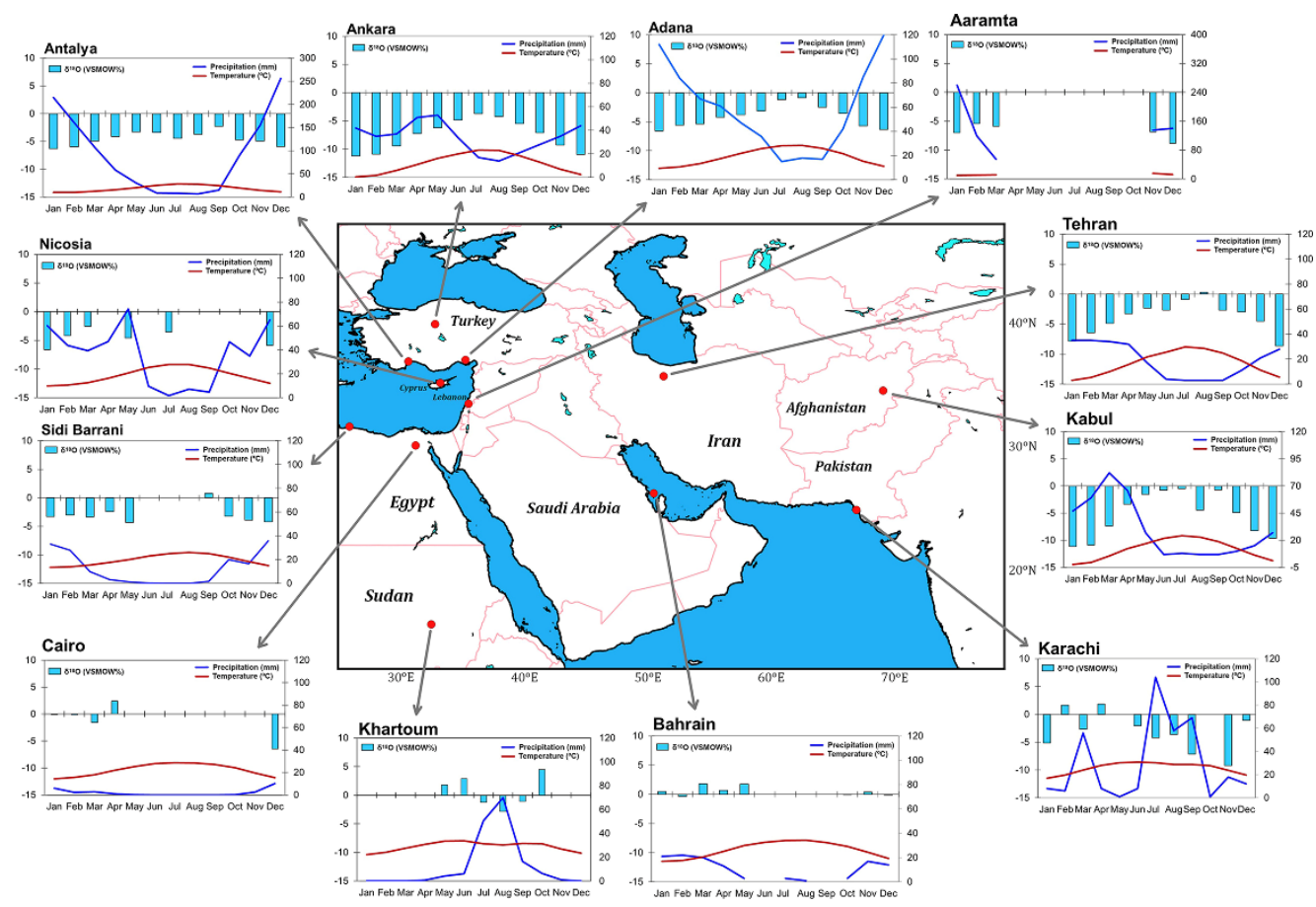

Figure 5. The monthly variations of $\delta^{18} \mathrm{O}$ stable isotopes, precipitation amount, and temperature in twelve stations across the Middle East. 
In the coastal stations (Karachi, Antalya, Bahrain, and Sidi Barrani), due to the higher relative humidity throughout the year in the atmosphere, the seasonal effect on the $\delta^{18} \mathrm{O}$ values of precipitation is not as significant as in the continental stations. Thus, the $\delta^{18} \mathrm{O}$ values have no obvious correlation with the precipitation amount and temperature. In contrast to the other coastal stations, the Karachi station, which is influenced by the Indian monsoon regime, shows high amounts of precipitation and depleted $\delta^{18} \mathrm{O}$ values in July, August, and September in the hot period (Figure 5) [58]. The monsoon regime affects large parts of Pakistan, Oman, and southeastern Iran during the hot period and causes intense precipitation events (Figure 1).

\subsection{The Classification of the Studied Stations}

Since studying the stable isotope characteristics of precipitation across the Middle East was very complicated due to various climatic conditions, the stations were classified based on the Köppen climate zones Table 2 [41,42]. The weighted means of the $\delta^{18} \mathrm{O}$ and $\delta^{2} \mathrm{H}$ values in the precipitation events of the stations located in the BWh zone showed the most enriched values during the hot and dry ( $-1.71 \%$ and $-3.98 \%$, respectively) as well as the cold and wet $(-2.42 \%$ and $-5.87 \%$, respectively) periods. This is due to the fact that the stations located in the BWh zone face a high air temperature and an intense evaporation, which enrich the stable isotope values in precipitation. However, the only station located in the Dsb zone (Erzurum) showed the most depleted $\delta^{18} \mathrm{O}$ and $\delta^{2} \mathrm{H}$ values both during the hot and dry $(-4.81 \%$ and $-27.71 \%$, respectively) as well as the cold and wet $(-11.29 \%$ and $-78.34 \%$, respectively) periods. This was because this station was located in a mountainous region with a high elevation and a low annual air temperature. The stable isotope values decline notably as elevation increases in mountainous regions. As a mass of vapor rises over the slope of a mountain and is simultaneously adiabatically cooled (by expansion), rainout occurs. At high elevations where the air temperature is lower, stable isotopes normally show more depleted isotope values. However, the gradient of isotope depletion by elevation increase varies from one place to another [25].

Table 2. The average stable isotope values in the studied stations based on the Köppen climate zones.

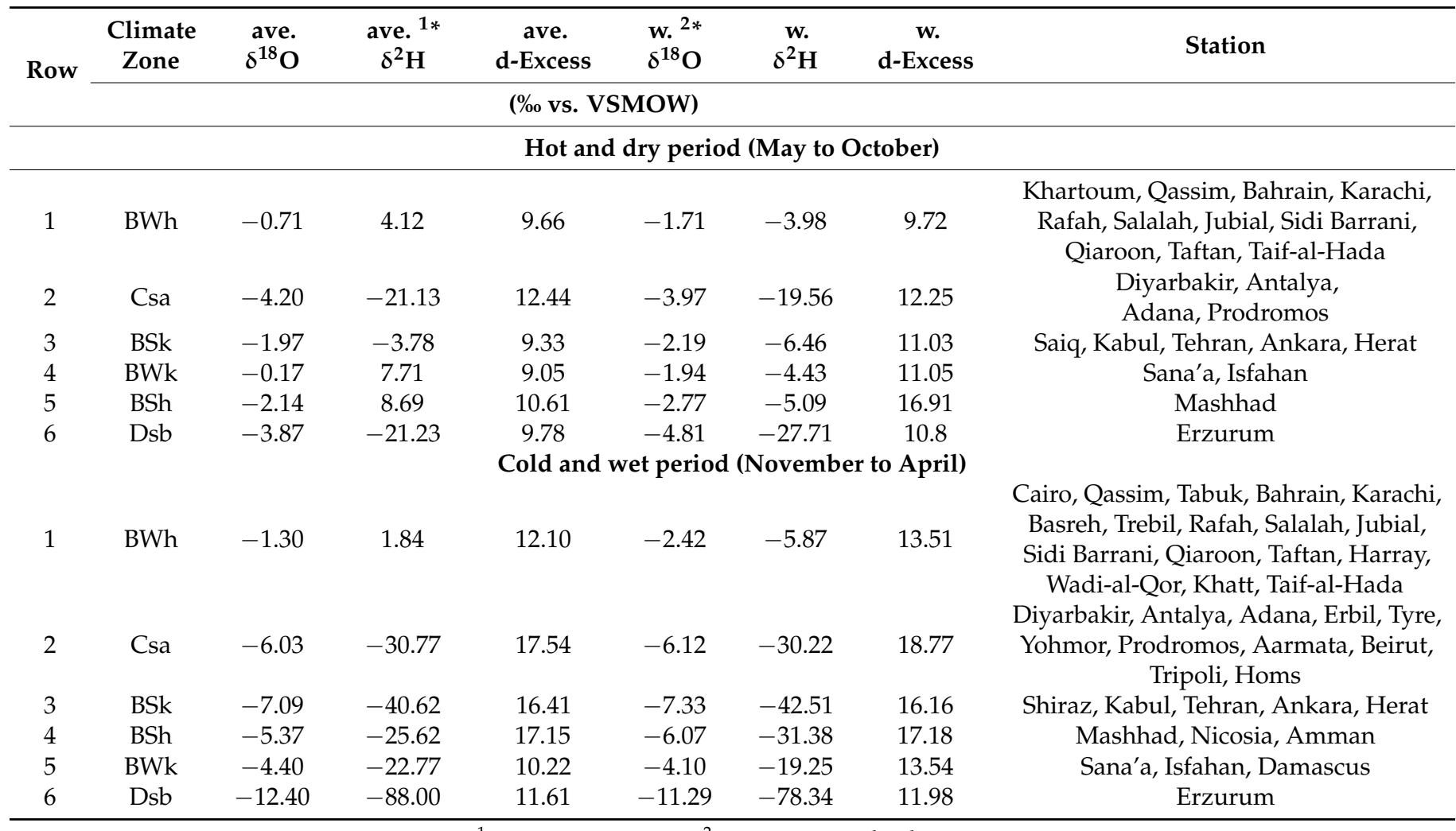

\footnotetext{
$1 *$ ave. means average, ${ }^{2 *} \mathrm{~W}$. means weighted mean.
} 
Regarding the d-excess values in precipitation across the Middle East Table 2, the stations located in the Csa and BSh climate zones showed the highest average d-excess values $(18.77 \%$ in the Csa climate zone during the cold and wet period and $16.91 \%$ in the BSh climate zone during the hot and dry period). This was because most of the moisture causing precipitation in the stations located in these zones was provided by the Mediterranean Sea. The role of the Mediterranean Sea moisture in these parts of the Middle East has also been confirmed by previous studies [37,59]. The stations located in the BWh climate zone showed the lowest d-excess values compared to those in the other zones during the hot and dry period. Although the stations located in the BWh zone received their precipitation moisture from water bodies with high SSTs (such as the Persian Gulf, the Mediterranean Sea, and the Red Sea), the lowest d-excess values at these stations were due to the effect of intense evaporation on precipitation in the sampling sites. The significant enrichment of the $\delta^{18} \mathrm{O}$ and $\delta^{2} \mathrm{H}$ values in the precipitation events of these stations also confirms the important effect of evaporation. During the cold and wet period, the only station located in the Dsb climate zone (Erzurum) showed the lowest d-excess value $(11.98 \%$ ) compared to the other climate zones across the Middle East. This was because most of the precipitation moisture in this station was provided by water bodies with low SSTs in high latitudes such as the Caspian Sea, the Black Sea, and the North Atlantic Ocean [37].

Plotting the stable isotopes in the studied stations based on their climate zones on the global meteoric water line (GMWL) and the eastern Mediterranean meteoric water line (EMMWL) showed that the stations located in the BWh climate zone were mainly plotted on the GMWL during the cold and wet period. However, the precipitation samples showed a mild deviation from both the GMWL and the EMMWL during the hot and dry period due to the effect of evaporation on the stable isotope values in precipitation (Figure 6). Intense evaporation caused a notable enrichment in the stable isotopes and their deviation from the meteoric water lines. Most of the stations in the Csa climate zone were located in the coastal area of the Mediterranean Sea or the nearby regions and were plotted on the EMMWL during the cold and wet period. This was normal as the main part of moisture for precipitation at these stations was provided by the Mediterranean Sea. The high average d-excess value $(18.77 \%$ ) of precipitation in the stations located in this zone also confirmed that the moisture originated from the Mediterranean Sea [60]. However, during the hot and dry period, a notable deviation from the EMMWL was observed in most stations of the Csa climate zone due to the significant effect of evaporation on the precipitation events. The stations located in the BSk climate zone were plotted between the GMWL and the EMMWL during the cold and wet period, because these stations received moisture for precipitation from various sources including water bodies with high SSTs (such as the Mediterranean Sea, the Red Sea, and the Persian Gulf) and water bodies with low SSTs (such as the Caspian Sea and the Black Sea). However, during the hot and dry period, a very mild deviation from both the EMMWL and the GMWL was observed in the stations located in this climate zone due to the effect of moderate evaporation on the precipitation events. Similar to the BSk climate zone, the stations located in the BSh zone were also plotted between the GMWL and the EMMWL during the cold and wet period. However, during the hot and dry period, a deviation from both meteoric water lines was observed due to the evaporation effect on the stable isotopes in precipitation. The stations located in the BWk climate zone (except for the Sana'a station) were mainly plotted on the GMWL and the EMMWL during the cold and wet period. The Sana'a station deviated from both meteoric water lines due to the intense evaporation affecting precipitation in this station. In contrast to the other stations, the Sana'a station showed more depleted stable isotope values during the hot and dry period than the cold and wet period. This was because most of the annual precipitation in this station occurred during the hot period. Due to the precipitation amount effect, more depleted stable isotope values were also observed during this period. Finally, in the Dsb climate zone, there was only one station (Erzurum). The precipitation events in this climate zone showed the most depleted stable isotope values 
compared with those in the other zones in the Middle East. These stable isotope values were plotted on the GMWL during the cold and wet as well as the hot and dry periods. This was because this station received most of the moisture for its precipitation from water bodies with low SSTs such as the Atlantic Ocean, the Black Sea, and the Caspian Sea However, during the hot and dry period, the precipitation events showed more enriched stable isotope values as well as a negligible deviation from the GMWL. As the Erzurum station was located in a high elevation with a very low evaporation rate, deviation from the GMWL was negligible during the hot and dry period.
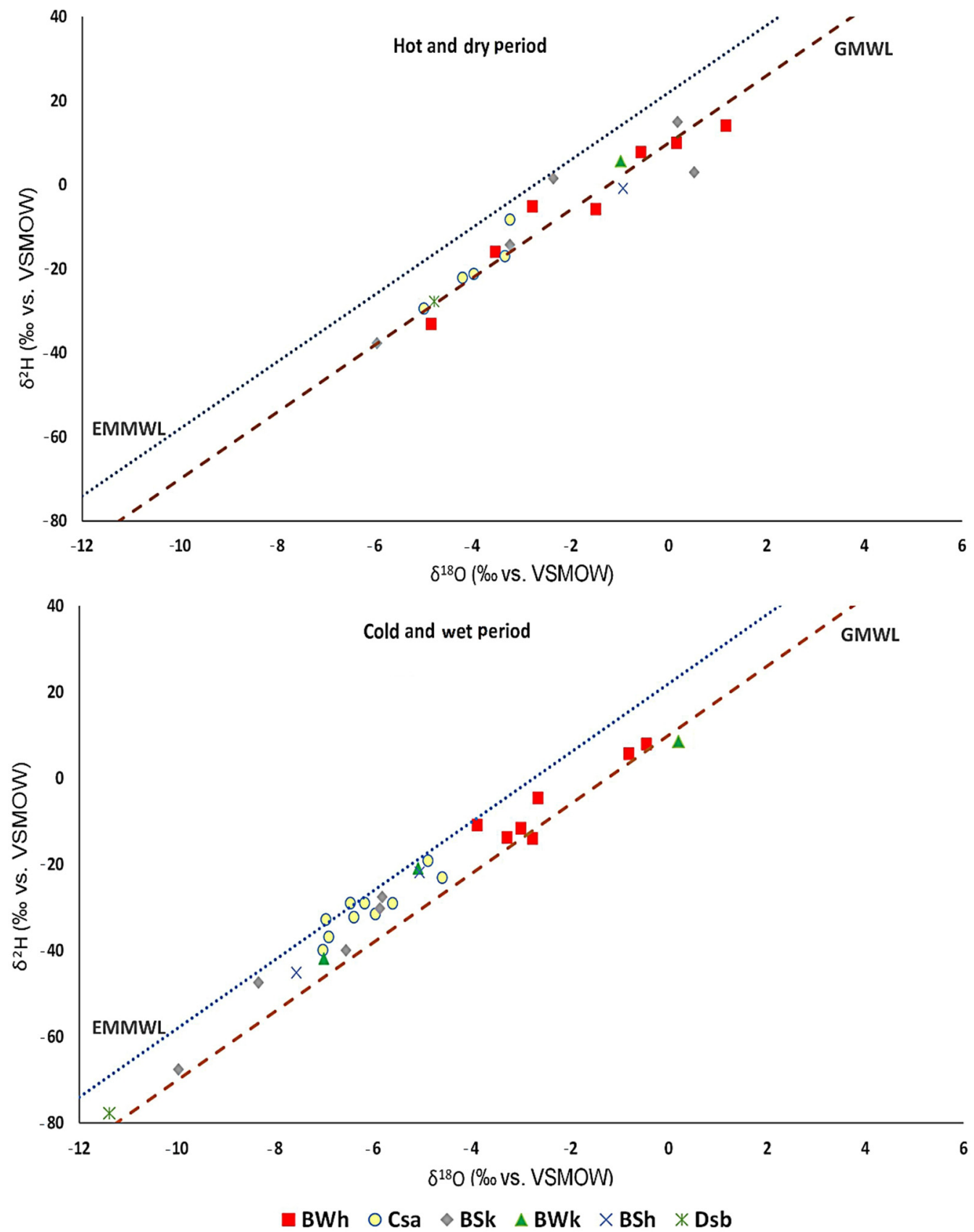

Figure 6. Plotting the stable isotopes in the studied stations on the EMMWL and the GMWL based on the Köppen climate zones.

The Middle East meteoric water line (MEMWL) was developed for the hot and dry as well as the cold and wet periods using the weighted mean of $\delta^{18} \mathrm{O}$ and $\delta^{2} \mathrm{H}$ values in the studied stations across the Middle East (Figure 7). 

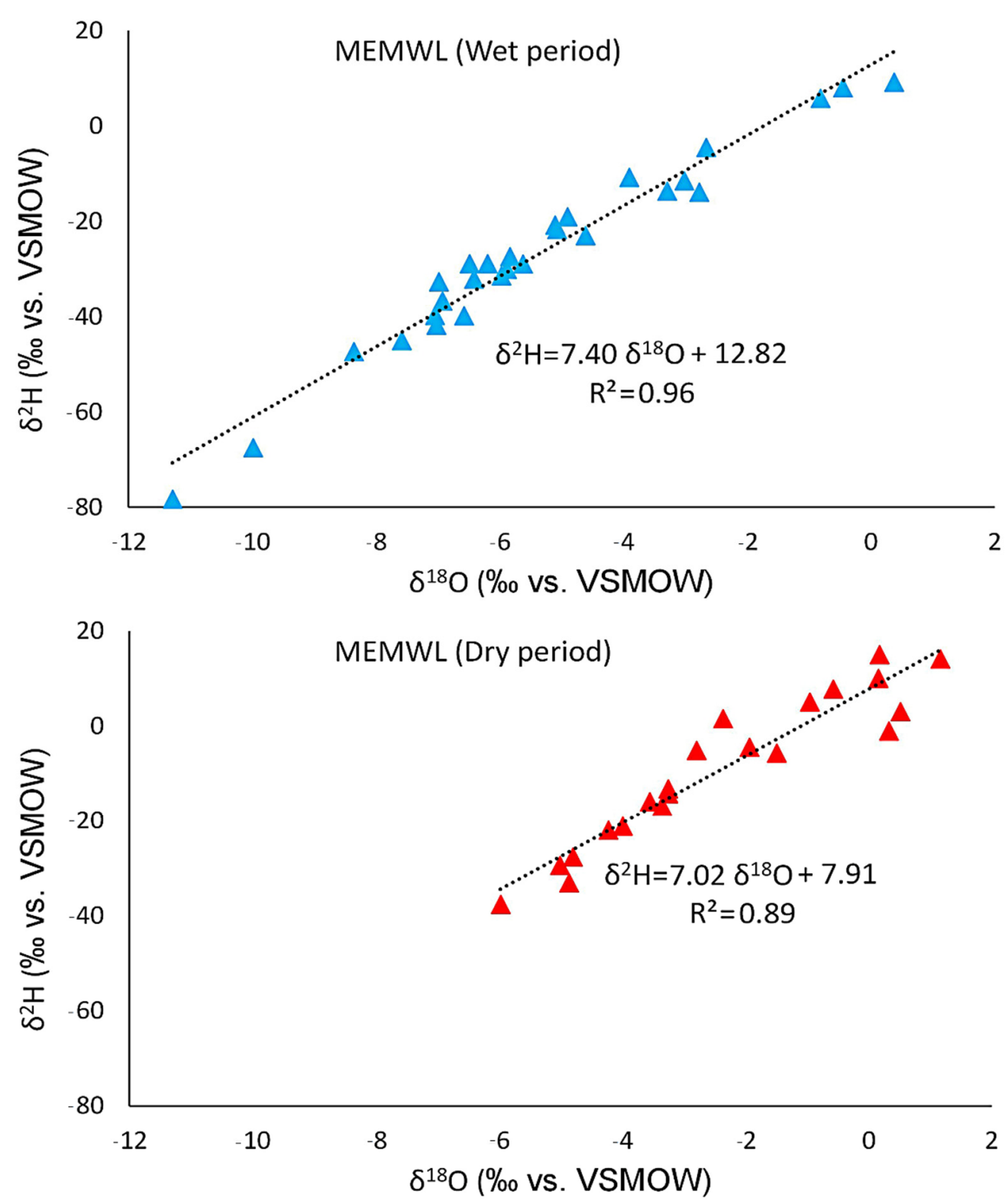

Figure 7. Developing the meteoritic water lines for the Middle East (MEMWL) in the hot and dry as well as the cold and wet periods.

The lower slope of the MEMWL for the cold and wet $\left(\delta^{2} \mathrm{H}=7.397( \pm 0.289) \delta^{18} \mathrm{O}\right.$ $\left.+12.823( \pm 1.725), \mathrm{R}^{2}=0.96\right)$ as well as the hot and dry $\left(\delta^{2} \mathrm{H}=7.015( \pm 0.567) \delta^{18} \mathrm{O}+7.908\right.$ $\left.( \pm 1.791), R^{2}=0.889\right)$ periods compared to that of the GMWL $\left(\delta^{2} \mathrm{H}=8.17 \delta^{18} \mathrm{O}+11.27\right.$ [61] $)$ was due to the high air temperature and the intense evaporation in the Middle East compared to the average global conditions. The intense evaporation in the stations across the Middle East causes a notable enrichment in the $\delta^{18} \mathrm{O}$ and $\delta^{2} \mathrm{H}$ values of precipitation as well as a decrease in the slope and intercept of the developed MEMWL, especially during the hot and dry period when the air temperature increases and the evaporation intensifies in this region.

\section{Conclusions}

This paper reviewed the stable isotope data of the GNIP stations and used previous studies to investigate the locally significant parameters affecting the stable isotopes in the precipitation of the Middle East. The geographical and climatological parameters which controlled the stable isotopes in the Middle East precipitation were examined in this study using stepwise regression model. Latitude was the main geographical parameter and tem- 
perature was the main climatological parameter correlating with the $\delta^{18} \mathrm{O}$ and $\delta^{2} \mathrm{H}$ values in precipitation. However, the precipitation amount, temperature, and elevation were statistically the most significant factors correlating with the d-excess values in precipitation. Furthermore, the stepwise model was used to develop empirical models for simulating the stable isotope values in precipitation across the Middle East. The map of the spatial distribution of the simulated stable isotopes in precipitation was also drawn. The stable isotope maps were validated by several precipitation checkpoints across the Middle East and RMSE was calculated for each developed map. Moreover, the stable isotope values in precipitation across the Middle East showed large variations, which highly correlated with the climate zones where the sampling stations were located. The stations located in the BWh climate zone showed the most enriched $\delta^{18} \mathrm{O}$ and $\delta^{2} \mathrm{H}$ values. However, Erzurum, which was the only station in the Dsb zone, showed the most depleted isotope values and was plotted on the GMWL during the hot and dry as well as the cold and wet periods. In addition to spatial variations, the $\delta^{18} \mathrm{O}$ values in precipitation also showed temporal variations in the studied stations across the Middle East. The $\delta^{18} \mathrm{O}$ values showed depletion with decrease in temperature and increase in precipitation amount in most of the studied stations during the cold and wet period. However, in some stations in the southern part of the Middle East (including Sana'a, Karachi, and Khartoum), most annual precipitation and depleted isotope values were observed during the hot period. Finally, the MEMWL was developed for the hot and dry as well as the cold and wet periods, which showed lower slopes than the GMWL due to the higher air temperature and evaporation rate in the Middle East compared with the average global conditions.

Supplementary Materials: The following are available online at https:/ / www.mdpi.com/article/ 10.3390/w13172397/s1. Table S1: The characteristics of the stable isotopes of the precipitation events, the precipitation amount, air temperature, station elevation, and Köppen climate zones in the studied stations across the Middle East. Table S2: Studying the effects of the meteorological and geographical parameters on the stable isotope values of precipitation using the stepwise technique.

Author Contributions: Conceptualization, M.H., R.S., F.M. and L.G.; methodology, M.H. and J.E.M.; software, M.H., J.E.M. and R.S.; formal analysis, M.H. and F.M.; investigation, M.H. and F.M.; resources, M.H., J.E.M. and R.S.; data curation, M.H. and R.S.; writing —original draft preparation, M.H.; supervision, L.G.; project administration, L.G. All authors have read and agreed to the published version of the manuscript.

Funding: This research received no external funding.

Institutional Review Board Statement: Not applicable.

Informed Consent Statement: Not applicable.

Data Availability Statement: Data will be available by request.

Acknowledgments: Our special thanks are extended to our colleagues at Ferdowsi University of Mashhad in Iran for their support during this study. R.S. acknowledges the postdoctoral fellowship (no. ED481B 2019/070) from the Xunta de Galicia.

Conflicts of Interest: The authors declare no conflict of interest.

\section{References}

1. Bozorg-Haddad, O.; Zolghadr-Asli, B.; Sarzaeim, P.; Aboutalebi, M.; Chu, X.; Loáiciga, H.A. Evaluation of water shortage crisis in the Middle East and possible remedies. J. Water Supply Res. Technol. 2020, 69, 85-98. [CrossRef]

2. Baconi, T. Testing the Water: How Water Scarcity Could Destabilise the Middle East and North Africa; ECFR: London, UK, 2018.

3. Zhai, Y.; Wang, J.; Zhang, Y.; Teng, Y.; Zuo, R.; Huan, H. Hydrochemical and isotopic investigation of atmospheric precipitation in Beijing, China. Sci. Total Environ. 2013, 456-457, 202-211. [CrossRef] [PubMed]

4. Chitsazan, M.; Vardanjani, H.K.; Karimi, H.; Charchi, A. A comparison between karst development in two main zones of Iran: Case study-Keyno anticline (Zagros range) and Shotori anticline (Central Iran). Arab. J. Geosci. 2015, 8, 10833-10844. [CrossRef]

5. Wu, H.; Huang, Q.; Fu, C.; Song, F.; Liu, J.; Li, J. Stable isotope signatures of river and lake water from Poyang lake, China: Implications for river-lake interactions. J. Hydrol. 2021, 592, 125619. [CrossRef] 
6. Xia, C.; Liu, G.; Wang, Z.; Meng, Y.; Chen, K.; Song, H.; Mei, J. Distribution of hydrogen and oxygen stable isotopes and pollution indicators in water during a monsoon transitional period in Min River Basin. Sci. Total Environ. 2021, 782, 146780. [CrossRef]

7. Wang, C.; Zheng, M.; Zhang, X.; Xing, E.; Zhang, J.; Ren, J.; Ling, Y. O, H, and Sr isotope evidence for origin and mixing processes of the Gudui geothermal system, Himalayas, China. Geosci. Front. 2020, 11, 1175-1187. [CrossRef]

8. Yang, N.; Zhou, P.; Wang, G.; Zhang, B.; Shi, Z.; Liao, F.; Li, B.; Chen, X.; Guo, L.; Dang, X.; et al. Hydrochemical and isotopic interpretation of interactions between surface water and groundwater in Delingha, Northwest China. J. Hydrol. 2021, $598,126243$. [CrossRef]

9. Jiang, Z.; Xu, T.; Mallants, D.; Tian, H.; Owen, D.D.R. Numerical modelling of stable isotope (2H and 18O) transport in a hydro-geothermal system: Model development and implementation to the Guide Basin, China. J. Hydrol. 2019, 569, 93-105. [CrossRef]

10. Moghadam, H.M.; Bagheri, R.; Karami, G.H.; Jafari, H. Groundwater origin in Qanats, chemo-isotopic, and hydrogeological evidence. Groundwater 2020, 58, 771-776. [CrossRef]

11. Marín, A.I.; Andreo, B.; Mudarra, M. Vulnerability mapping and protection zoning of karst springs. Validation by multitracer tests. Sci. Total Environ. 2015, 532, 435-446. [CrossRef]

12. Lachniet, M.S.; Patterson, W.P. Oxygen isotope values of precipitation and surface waters in northern Central America (Belize and Guatemala) are dominated by temperature and amount effects. Earth Planet. Sci. Lett. 2009, 284, 435-446. [CrossRef]

13. Wen, R.; Tian, L.; Weng, Y.; Liu, Z.; Zhao, Z. The altitude effect of $\delta 18 \mathrm{O}$ in precipitation and river water in the Southern Himalayas. Chin. Sci. Bull. 2012, 57, 1693-1698. [CrossRef]

14. Fricke, H.C.; O'Neil, J.R. The correlation between 18O/16O ratios of meteoric water and surface temperature: Its use in investigating terrestrial climate change over geologic time. Earth Planet. Sci. Lett. 1999, 170, 181-196. [CrossRef]

15. Mohammadzadeh, H.; Heydarizad, M. A conceptual model for water resources circulation patterns in Andarokh-Kardeh region (NE, Iran). Geochemistry 2020, 80, 125593. [CrossRef]

16. Shamsi, A.; Karami, G.H.; Taheri, A.; Hunkeler, D. Hydrochemistry and stable isotopes study of the precipitation at Haraz Basin, north of Iran. Geopersia 2020, 10, 23-39. [CrossRef]

17. Heydarizad, M. Investigation of Hydrochemistry of Karde Dam and Its Hydraulically Connection with Downstream Water Resources; Ferdowsi University of Mashhad: Mashdad, Iran, 2011.

18. Craig, H. Isotopic variations in meteoric waters. Science 1961, 133, 1702-1703. [CrossRef] [PubMed]

19. Dansgard, W. Stable isotopes in precipitation. Tellus 1964, 16, 436-468. [CrossRef]

20. Longinelli, A.; Anglesio, E.; Flora, O.; Iacumin, P.; Selmo, E. Isotopic composition of precipitation in Northern Italy: Reverse effect of anomalous climatic events. J. Hydrol. 2006, 329, 471-476. [CrossRef]

21. Rao, W.; Zhang, W.; Yong, B.; Tan, H.; Meredith, K.T.; Jin, K.; Zheng, F.; Wang, S. Identifying the source of atmospheric moisture over arid deserts using stable isotopes (2H and 18O) in precipitation. Hydrol. Process. 2018, 32, 436-449. [CrossRef]

22. Yu, W.; Yao, T.; Tian, L.; Ma, Y.; Ichiyanagi, K.; Wang, Y.; Sun, W. Relationships between $\delta 18 \mathrm{O}$ in precipitation and air temperature and moisture origin on a south-north transect of the Tibetan plateau. Atmos. Res. 2008, 87, 158-169. [CrossRef]

23. Jouzel, J.; Froehlich, K.; Schotterer, U. Deuterium and oxygen-18 in present-day precipitation: Data and modelling. Hydrol. Sci. J. 1997, 42, 747-763. [CrossRef]

24. Clark, I.D. Groundwater Geochemistry and Isotopes; CRC Press: Boca Raton, FL, USA, 2015.

25. Clark, I.D.; Fritz, P. Environmental Isotopes in Hydrogeology, 2nd ed.; CRC Press: Boca Raton, FL, USA, 1997 ; ISBN 1566702496.

26. Heydarizad, M. Meteoric Water Lines of Iran for Various Precipitation Sources; Shiraz University: Shiraz, Iran, 2018.

27. Heydarizad, M.; Raeisi, E.; Sorí, R.; Gimeno, L. An overview of the atmospheric moisture transport effect on stable isotopes $(\delta 18 \mathrm{O}, \delta 2 \mathrm{H})$ and $\mathrm{D}$ excess contents of precipitation in Iran. Theor. Appl. Climatol. 2019. [CrossRef]

28. Mohammadzadeh, H.; Heydarizad, M. $\delta 18 \mathrm{O}$ and $\delta 2 \mathrm{H}$ characteristics of moisture sources and their role in surface water recharge in the north-east of Iran. Isot. Environ. Health Stud. 2019, 55, 550-565. [CrossRef] [PubMed]

29. Mohammadzadeh, H.; Mayvan, J.E.; Heydarizad, M. The effects of moisture sources and local parameters on the $18 \mathrm{O}$ and $2 \mathrm{H}$ contents of precipitation in the west of Iran and the east of Iraq. Tellus B Chem. Phys. Meteorol. 2020, 72, 1-15. [CrossRef]

30. Kazemi, G.A.; Ichiyanagi, K.; Shimada, J. Isotopic characteristics, chemical composition and salinization of atmospheric precipitation in Shahrood, northeastern Iran. Environ. Earth Sci. 2015, 73, 361-374. [CrossRef]

31. Farpoor, M.H.; Khademi, H.; Eghbal, M.K.; Krouse, H.R. Mode of gypsum deposition in southeastern Iranian soils as revealed by isotopic composition of crystallization water. Geoderma 2004, 121, 233-242. [CrossRef]

32. Khademi, H.; Mermut, A.R.; Krouse, H.R. Isotopic composition of gypsum hydration water in selected landforms from central Iran. Chem. Geol. 1997, 138, 245-255. [CrossRef]

33. Ali, K.K.; Al-Kubaisi, Q.Y.; Al-Paruany, K.B. Isotopic study of water resources in a semi-arid region, western Iraq. Environ. Earth Sci. 2015, 74, 1671-1686. [CrossRef]

34. Mashiatullah, A.; Qureshi, R.M.; Tasneem, M.A.; Javed, T.; Gaye, C.B.; Ahmad, E.; Ahmad, N. Isotope hydrochemical investigation of saline intrusion in the coastal aquifer of Karachi, Pakistan. Radioact. Environ. 2006, 8, 382-393.

35. Macumber, P.; Niwas, J.; Al Abadi, A.; Seneviratne, R. A new isotopic water line for northern Oman. In Proceedings of the Third Gulf Water Conference, Muscat, Sultanate of Oman, 8-13 March 1997.

36. Heydarizad, M.; Minaei, M.; Ichiyanagi, K.; Sorí, R. The effects of local and regional parameters on the $\delta 18 \mathrm{O}$ and $\delta 2 \mathrm{H}$ values of precipitation and surface water resources in the Middle East. J. Hydrol. 2021, 600, 126485. [CrossRef] 
37. Mohebi, A. Studying the parameters influenceing precipitation variations across Middle East. Water Resour. 2012, 15, 205-209.

38. Alijani, B. Iran Climatology, 5th ed.; Payam Nour Publication: Tehran, Iran, 2000; ISBN 978-964-455-621-0.

39. Heydarizad, M.; Raeisi, E.; Sori, R.; Gimeno, L. The identification of Iran's moisture sources using a Lagrangian particle dispersion model. Atmosphere 2018, 9, 408. [CrossRef]

40. Dee, D.P.; Uppala, S.M.; Simmons, A.J.; Berrisford, P.; Poli, P.; Kobayashi, S.; Andrae, U.; Balmaseda, M.A.; Balsamo, G.; Bauer, P.; et al. The ERA-interim reanalysis: Configuration and performance of the data assimilation system. Q. J. R. Meteorol. Soc. 2011, 137, 553-597. [CrossRef]

41. Rudolf, G. Klassifikation der klimate nach W. Köppen. (Classification of climates after W. Köppen). Landolt-Börnstein-Zahlenwerte Funkt. Phys. Chemie Astron. Geophys. Tech. Ser. 1954, 3, 603-607.

42. Rudolf, G. Köppen-Geiger-Klima der Erde; von Geiger, R., Ed.; Klett-Perthes: Gotha, Germany, 1961; Volume 3.

43. Beck, H.; Zimmermann, N.; McVicar, T.; Vergopolan, N.; Berg, A.; Wood, E. Present and future Köppen-Geiger climate classification maps at 1-km resolution. Sci. Data 2018, 5, 180214. [CrossRef] [PubMed]

44. Faroughi, A. Characterizing Isotopic Signature of Precipitation in Fars Province, Iran; Shiraz University: Shiraz, Iran, 2008.

45. Mousavi, M.; Ataei, A.; Jaghouri, A.; Vaghefi, M. Studying water resources quality in Herat, Afghanistan. Water Resour. Qual. 2017, 2, 24-45.

46. Lachniet, M.S.; Patterson, W.P. Use of correlation and stepwise regression to evaluate physical controls on the stable isotope values of Panamanian rain and surface waters. J. Hydrol. 2006, 324, 115-140. [CrossRef]

47. Unland, N.P.; Cartwright, I.; Andersen, M.S.; Rau, G.C.; Reed, J.; Gilfedder, B.S.; Atkinson, A.P.; Hofmann, H. Investigating the spatio-temporal variability in groundwater and surface water interactions: A multi-technique approach. Hydrol. Earth Syst. Sci. 2013, 17, 3437-3453. [CrossRef]

48. R Core Team. R: A Language and Environment for Statistical Computing; R Foundation for Statistical Computing: Vienna, Austria, 2018.

49. QGIS. Development Team QGIS Geographic Information System. 2021. Available online: https://qgis.org/en/site/index.html (accessed on 30 August 2021).

50. Minaei, M.; Minaei, F. Geostatistical modeling of air temperature using thermal remote sensing. Am. J. Environ. Sci. Eng. 2017, 1,103-109.

51. Morad, A. Stable isotope characterstic of the Amman precipitation. Reg. Water 2015, 10, $25-43$.

52. Mohammadzadeh, H.; Ebrahimpour, S. Application of stable isotopes and hydrochemistry to investigate sources and quality exchange Zarivar catchment area. J. Water Soil 2012, 26, 1018-1031.

53. Hussain, S.; Song, X.; Hussain, I.; Jianrong, L.; Dong Mei, H.; Li Hu, Y.; Huang, W. Controlling factors of the stable isotope composition in the precipitation of Islamabad, Pakistan. Adv. Meteorol. 2015. [CrossRef]

54. Banks, D. A Hydrogeological Atlas of Faryab Province, Northern Afghanistan; Project Report; NORPLAN: Sandvika, Norway, 2014.

55. Kohn, M.J.; Welker, J.M. On the temperature correlation of $818 \mathrm{O}$ in modern precipitation. Earth Planet. Sci. Lett. 2005, 231, 87-96. [CrossRef]

56. Salih, A.A.M.; Zhang, Q.; Pausata, F.S.R.; Tjernström, M. Sources of Sahelian-Sudan moisture: Insights from a moisture-tracing atmospheric model. J. Geophys. Res. Atmos. 2016, 121, 7819-7832. [CrossRef]

57. Salih, A.A.M.; Zhang, Q.; Tjernstrom, M. Lagrangian tracing of Sahelian Sudan moisture sources. J. Geophys. Res.-Atmos. 2015, 120, 6793-6808. [CrossRef]

58. Rasul, G.; Chaudhry, Q.; Sixiong, Z.; Qingcun, Z.; Linlin, Q.; Gaoying, Z. A diagnostic study of heavy rainfall in Karachi due to merging of a mesoscale low and a diffused tropical depression during South Asian summer monsoon. Adv. Atmos. Sci. 2005, 22, 375-391. [CrossRef]

59. Ghorehchi, H. Surface water resources vulnerability assessment in Middle East. Iran Water Monit. 2001, 4, 25-36.

60. Gat, J.R.; Carmi, I. Evolution of the isotopic composition of atmospheric waters in the Mediterranean Sea area. J. Geophys. Res. 1970, 75, 3039-3048. [CrossRef]

61. Rozanski, K.; Araguas-Araguas, L.; Gonfiantini, R. Isotopic patterns in modem global precipitation. In Climate Change in Continental Isotopic Records; Swart, P.K., Lohmann, K.C., Mckenzie, J., Savin, S., Eds.; Geophysical Monograph Series; American Geophysical Union: Washington, DC, USA, 1993; pp. 1-36, ISBN 9781118664025. 